\title{
KEHIDUPAN MASYARAKAT ADAT KAMPUNG BANCEUY: KEBERTAHANAN ADAT ISTIADAT MENGHADAPI PERUBAHAN SOSIAL- BUDAYA (Kajian Historis Tahun 1965-2008)
}

Oleh

\author{
Selma Nurul Afifah dan Syarif Moeis ${ }^{1 / 1}$
}

\begin{abstract}
ABSTRAK
Penelitian ini bertujuan untuk menjelaskan perkembangan kehidupan masyarakat kampung adat Banceuy yang sangat berbeda dengan masyarakat desa pada umumnya. Kampung adat Banceuy merupakan salah satu masyarakat di Kabupaten Subang yang masih mempertahankan tradisi atau adat istiadat yang dilakukan oleh para leluhurnya. Kehidupan masyarakat Banceuy dalam rentang waktu 43 tahun memiliki banyak perubahan dalam bidang sosial-budaya. Perubahan-perubahan tersebut berjalan seiring dengan sejarah kehidupan masyarakat Kampung Adat Banceuy itu sendiri. Perubahanperubahan tersebut dipengaruhi oleh faktor eksternal dan internal. Selain faktor eksternal dan internal, terdapat pula faktor-faktor yang mendorong serta menghambat terjadinya perubahan. Hal-hal tersebut mengakibatkan terjadinya perubahan-perubahan pada nilainilai yang tidak mengikat. Sedangkan nilai-nilai yang mengikat seperti adat istiadat di Kampung Banceut selalu bertahan seiring perubahan jaman.
\end{abstract}

Kata Kunci : Kampung adat Banceuy, kebertahanan adat istiadat, Perubahan SosialBudaya

\begin{abstract}
This study aims to explain the development of the villager life's from Banceuy traditional hamlet which is very different from other villager in generals. Banceuy traditional hamlet are one of the society located in Subang that still retains their ancestor's tradition or custom. The 43 years span show that The Banceuy traditional villagers have gone through so many changes especially in socio-cultural field. The changes happened as time of historical goes on in traditional Banceuy villagers themselves. These changes are influenced by external and internal factors, there are some factors that encourage and inhibit the changes. In this case effects some changes in the value that is not inherent. While the inherent value which is the tradition in Banceuy villagers always kept well reserved with the changes of the era.
\end{abstract}

Keywords: traditional banceuy villagers, the changes of sosio-cultural field, the existance of tradition.

\footnotetext{
${ }^{1}$ Penulis adalah mahasiswa Departemen Pendidikan Sejarah, Fakultas Pendidikan Ilmu Pengetahuan Sosial, Universitas Pendidikan Indonesia. Ayi Budi Santosa (Pembimbing I) dan Syarif Moeis (Pembimbing II). Penulis dapat dihubungi melalui nomor 087760781118/Email: selma.nurulafifah@yahoo.com
} 


\section{PENDAHULUAN}

Indonesia memiliki beragam macam etnik dan budaya yang sampai saat ini masih menjadi daya tarik berbagai pihak untuk dijadikan sebagai bahan penelitian ataupun menjadi pusat daya tarik pariwisata. Berbagai suku dan budaya di Indonesia sebagian besar masih mewarisi kebudayaan nenek moyang ataupun leluhurnya. Salah satu suku dan budaya di Indonesia adalah suku Sunda. Suku dan budaya Sunda memiliki corak khas yang berbeda dari kebudayaan lainnya. Kebudayaan Sunda mempunyai kepribadian dan identitas khususnya, dan tentunya berbeda dengan kebudayaankebudayaan suku lainnya (Koentjaraningrat, 2009, hlm. 214-215). Rasa identitas tersebut mengakibatkan di Jawa Barat yang mayoritas suku Sunda banyak terdapat kampung/desa adat. Desa adat merupakan sebuah kesatuan masyarakat hukum adat yang secara historis mempunyai batas wilayah dan identitas budaya yang terbentuk atas dasar teritorial yang berwenang mengatur dan mengurus kepentingan masyarakat desa berdasarkan hak asal-usul (Asshiddiqie, 2014, hlm. 1).

Daerah Jawa Barat memiliki beberapa macam masyarakat yang memiliki ciri-ciri sebagai masyarakat tradisional salah satunya adalah Kampung Adat Banceuy. Disebut sebagai kampung adat Banceuy dikarenakan dalam kehidupan sehari-harinya, masyarakat Banceuy masih memelihara dan menjaga adat istiadat yang diwarisi oleh nenek moyangnya seperti hal nya masih memiliki rasa bahwa alam merupakan bagian dari manusia. Manusia itu tetap sebagai bagian dari alam, tidak dapat menyatakan diri sebagai penguasa. Hal ini memperlihatkan bahwa umat manusia dihadapkan pada proses interaksi dan adaptasi dengan lingkungan alam disekitarnya. Kampung Banceuy masih menganggap bahwa alam bagian dari mereka. Hal tersebut dapat dilihat dari banyaknya upacara adat yang dilakukan seperti ngaruwat bumi yang setiap tahun menjadi suatu hal yang harus dilakukan agar tidak terjadi suatu bencana yang disebabkan oleh kemarahan alam.

Seiring berjalanya waktu, pertumbuhan teknologi dan informasi yang berkembang dengan pesatnya menyebabkan arus globalisasi saat ini sudah tidak bisa dikendalikan dan tidak terbantahkan, tidak terkecuali terhadap aspek sosial dan budaya. Pemikiran manusiapun semakin berkembang pula, karena manusia merupakan makhluk 
hidup yang memiliki akal pikiran yang berkembang dan dapat dikembangkan. Seiring berjalanya waktu, manusia mulai menunjukan egosentrisme untuk menguasai dan mengeksploitasi alam (Supriatna, 2013, hlm.1). Sehingga terdapat perubahan dari arah ecosentrisme menuju arah anthropocentrisme. Dimana kala itu manusia masih menjadikan alam bagian dari mereka (ecosntrisme), tetapi seiring berjalanya waktu manusia dapat menjadi penguasa alam (anthropocentrisme). Begitupun dengan masyarakat Banceuy itu sendiri, dikala arus globalisasi tidak bisa dihindari dengan berubahnya beberapa aspek kehidupan secara fisik, namun mereka tidak merubah suatu hal yang mereka anggap abstrak yaitu sebagai nilai atau adat istiadat yang telah lama mereka miliki. Maka dengan adanya hal tersebut kampung adat Banceuy memiliki suatu pedoman hidup yang tercermin dalam sebuah slogan yaitu "Ngindung ka Waktu Ngula ka Jaman" yang artinya pada sisi lain mereka tidak menolak perubahan, tetapi disisi lain untuk nilai atau adat istiadat tetap tidak bisa diganggu gugat dan tetap dipertahankan.

Perubahan kehidupan dalam masyarakat kampung Banceuy tidak akan lepas dari proses perkembangan secara bertahap dan berkesinambungan dengan semakin majunya perkembangan hidup manusia dan peranan juga fungsi dari kampung adat tersebut. Perkembangan dan perubahan yang terjadi seiring dengan adanya suatu peristiwa yang terjadi dalam kehidupan masyarakat Kampung Banceuy. Selain itu masuknya teknologi modern seperti adanya listrik, sarana dan prasarana transportasi, adanya suatu pembangunan di kampung tersebut, serta dijadikanya kampung Banceuy sebagai kampung adat dan daya tarik sebagai kampung wisata menyebabkan orang luar mudah masuk dan orang dalam mudah untuk keluar dari kampung tersebut. Semua fenomena tersebut dapat mempengaruhi perubahan sosial dan budaya yang terjadi dalam masyarakat Banceuy itu sendiri. Adanya kenyataan tersebut mengakibatkan perubahan sosial yang mungkin merupakan suatu kemajuan atau kemunduran yang bersifat menguntungkan ataupun merugikan.

Berdasarkan beberapa pokok pemikiran yang diuraikan di atas, maka penulis merumuskan masalah utama yang akan dibahas dalam kajian penelitian, yaitu "Bagaimana perubahan-perubahan yang terjadi dalam kehidupan sosialbudaya masyarakat tradisional Kampung 
Banceuy Desa Sanca Kabupaten Subang (Tahun 1965-2008)?”. Untuk lebih memfokuskan kajian penelitian ini dibatasi dalam beberapa pertanyaan, sebagai berikut: 1) Bagaimana latar belakang kehidupan masyarakat tradisonal Kampung Banceuy Desa Sanca Kabupaten Subang? 2) Bagaimana perubahan-perubahan yang terjadi dalam kehidupan masyarakat tradisional Kampung Banceuy khususnya dalam bidang sosial-budaya tahun 1965-2008? 3) Bagaimana kebertahanan adat istiadat masyarakat tradisional Kampung Banceuy terhadap perubahan-perubahan yang terjadi dalam bidang sosial-budaya tahun 1965-2008. Dari latar belakang tersebut, terdapat juga tujuan dan manfaat penelitian yaitu dapat mengidentifikasi latar belakang kehidupan masyarakat tradisional Kampung Banceuy Desa Sanca Kabupaten Subang, mengidentifikasi perubahan-perubahan yang terjadi dalam kehidupan masyarakat tradisional Kampung Banceuy khususnya dalam bidang sosial-budaya tahun 19652008, serta kebertahanan adat istiadat Masyarakat Tradisional Kampung Banceuy terhadap perubahan-perubahan yang terjadi dalam bidang sosial-budaya tahun 1965-2008.
Adapun manfaat dalam penelitian adalah ini bagi dunia pendidikan adalah hasil penelitian ini dapat menambah khazanah pengetahuan mengenai Sejarah Lokal, khususnya Sejarah Lokal yang ada di daerah Kabupaten Subang. Selain itu, menjadi bahan materi ajar bagi calon guru dalam pembelajaran sejarah mengenai perkembangan suatu masyarakat dari suatu lokalitas tertentu dari waktu ke waktu. Manfaat lain bagi masyarakat yang peduli akan sejarah pada umumnya dan masyarakat sekitar yang peduli akan perubahan-perubahan yang terjadi dalam kehidupan masyarakat. Khususnya peneliti berharap artikel ini bisa menjadi salah satu sumber informasi yang bermanfaat terlebih mengenai perkembangan suatu masyarakat melalui tinjauan historis dan manfaat nyata dari penelitian yang dituangkan dalam artikel ini diharapkan bisa menjadi bacaan masyarakat umum dengan harapan agar bisa memberi gambaran mengenai pentingnya memahami perkembangan kehidupan masyarakat.

\section{METODE PENELITIAN}

Metode yang digunakan dalam penelitian ini adalah metode historis dengan pendekatan interdisipliner yang menggunakan bantuan ilmu sosial 
lainnya seperti disiplin ilmu Sosiologi dan Antropologi. Untuk pengumpulan data yaitu menggunakan teknik wawancara, studi kepustakaan, dan studi dokumentasi. Metode historis adalah proses menguji dan menganalisis secara kritis rekaman dan peninggalan masa lampau dan menuliskan hasilnya berdasarkan fakta yang telah diperoleh yang disebut historiografi (Gottschalk, 1986, hlm.32).

Penulis membagi tahap-tahap penelitian sejarah sebagaimana yang diungkapkan oleh Ismaun (2005, hlm. 34) dalam buku Sejarah sebagai Ilmu. Tahap pertama adalah Heuristik, yaitu pencarian dan pengumpulan sumber sejarah yang relevan dengan topik yang dipilih dalam melakukan heuristik, sumber-sumber yang digunakan adalah studi literatur, wawancara, dan studi dokumentasi. Tahap kedua adalah kritik, yaitu memilah, menilai dan menyaring otentisitas dan kredibilitas sumbersumber yang telah ditemukan. Pada tahap ini penulis melakukan pengkajian sumber-sumber yang didapat untuk mendapatkan kebenaran sumber. Tahap ketiga adalah interpretasi, yaitu memaknai atau memberikan penafsiran terhadap fakta-fakta yang telah diperoleh dengan cara menghubungkan satu dengan yang lainnya. Tahap terakhir yaitu Historiografi, yakni menyusun dalam bentuk tulisan dengan jelas dengan gaya bahasa yang sederhana menggunakan tata bahasa penulisan yang baik dan benar.

Tahap pertama dalam melakukan penelitian seperti yang diungkapkan di atas adalah pencarian sumber tertulis. Pencarian sumber tertulis ini merupakan suatu hal yang pertama kali dilakukan oleh penulis dalam melakukan proses penelitian. Sumber-sumber tertulis tersebut, ditemukan oleh penulis diberbagai tempat yang berbeda dengan rentang waktu yang berbeda pula seperti melakukan pencarian ke perpustakan Universitas yang ada di Bandung ataupun ke berbagai tenpat yang relevan dengan penelitian. Selain sumber tertulis, terdapat pula sumber lisan. Dalam melakukan wawancara, penulis mengkategorikan narasumber yaitu sebagai saksi dan pelaku setiap peristiwa. Saksi merupakan yang melihat dan mengetahui bagaimana peristiwa itu terjadi misalnya masyarakat sekitar. Sedangkan pelaku merupakan orangorang yang benar-benar mengalami atau terlibat langsung dalam peristiwa tersebut seperti institusi pemerintahan atau sesepuh kampung Banceuy itu sendiri. Pencarian narasumber dilakukan penulis 
pada awal bulan Desember 2015 ketika melakukan pra-penelitian.

Setelah melakukan tahap pencarian sumber baik tertulis maupun lisan, pada tahap ini penulis berupaya melakukan kritik terhadap berbagai sumber yang telah penulis temukan baik berupa buku, jurnal, internet, maupun sumber tertulis lainnya yang dianggap relevan baik secara eksternal ataupun internal. Pada tahap penelitian kritik sumber, langkah pertama yang dilakukan oleh penulis adalah melakukan penilaian terhadap fisik buku sumber yang disebut dengan kritik eksternal terhadap buku buku yang ditulis oleh Edi S Ekadjati (1965). Prof. DR. H. Edi Suhardi Ekadjati yang berjudul Masyarakat dan Kebudayaan Sunda dan Kebudayaan Sunda Suatu Pendekatan Sejarah. Selain itu terhadap buku yang ditulis oleh Robert H. Lauer (1993) yang berjudul Perpektif Tentang Perubahan Sosial. Selanjutnya terhadap buku yang ditulis oleh Koentjaraningrat (1970) yang berjudul Manusia dan Kebudayaan di Indonesia dan (2009) yang berjudul Pengantar Antropologi. Serta terhadap buku yang ditulis oleh C.A. van Peursen (1988) yang berjudul Strategi Kebudayaan. Selain itu juga penulis melakukan kritik eksternal terhadap sumber lisan dengan cara mengetahui latar belakang narasumber. Setelah melakukan kritik eskternal, penulis juga melakukan kritik internal terhadap sumber tertulis dan sumber lisan yang paling dipercaya. Dalam melakukan kritik internal, penulis membandingkan beberapa sumber tertulis dan membandingkan beberapa sumber lisan.

Tahap berikutnya yang ditempuh dalam penelitian ini adalah tahap interpretasi. Dalam melakukan penafsiran terhadap fakta-fakta sejarah yang di temukan. Penulis menggunakan pendekatan interdisipliner, sehingga penulis memerlukan ilmu-ilmu bantu lainnya dalam mengkaji pembahasan ini. Ilmu bantu yang penulis pakai ialah ilmu bantu Soiologi dan Antropologi.

Pada tahap terakhir, yaitu historiografi, penulis menuangkan hasil penelitian kedalam bentuk tulisan. Dalam historiografi penulis menceritakan halhal yang didapat disertai dengan penafsiran-penafsirannya sehingga hasil dari historiografi berupa rekonstruksi utuh dari peristiwa sejarah.

\section{HASIL PENELITIAN DAN PEMBAHASAN}

Berdasarkan letak geografis, Kampung Banceuy berada pada daerah dataran tinggi atau pegunungan. Hal 
tersebut, terlihat dalam pembagian letak geografis Kabupaten Subang. Kampung Banceuy sendiri jika dilihat berdasarkan letak geografis Kabupaten Subang berada di daerah dataran tinggi atau pegunungan di bagian Selatan tepatnya di Kecamatan Ciater. Kampung Banceuy berada pada ketinggian 770 meter di atas permukaan laut. Suhu rata-rata di wilayah tersebut berada pada kisaran $26-28^{\circ} \mathrm{c}$. Sementara itu curah hujan setiap tahunnya adalah $2.700 \mathrm{~mm}$. Kondisi topografi wilayah ini terdiri atas dataran dan perbukitan atau pegunungan.

Luas wilayah kampung Banceuy mencapai 157 hektar, 47 hektar dari luas tersebut adalah hutan, 78 hektar berupa sawah, 20 hektar kebun, dan 12 hektar merupakan lahan hunian penduduk. Hutan, kebun, dan sawah merupakan sumber daya alam yang ada di kampung Banceuy. Hal ini memperlihatkan bahwa area wilayah pemukiman luasnya lebih sedikit dibandingkan dengan wilayah hutan dan area pesawahan. Hal ini memperlihatkan bahwa kehidupan masyarakat Banceuy masih sangat tergantung pada alam. Hal tersebut sejalan dengan pernyataan R. Firth dkk (Tanpa tahun, hlm.42) yang mengatakan bahwa yang terpenting dalam menentukan kebudayaan manusia adalah keadaan alam sekelilingnya.

Pola perkampungan Banceuy tergolong pola perkampungan yang linier. Pola seperti itu ditandai dengan adanya jalan raya atau jalan kampung, dan daerah perkampungan di sepanjang jalan tersebut. Unsur-unsur yang melengkapi pola perkampungan Banceuy terdiri atas rumah-rumah penduduk, sarana peribadatan, sarana pendidikan, sarana untuk berwirausaha, dan sarana olahraga. ternyata Kampung Banceuy ini tidak memiliki kekhasan tersendiri dalam bentuk fisik bangunan tetapi dalam kenyataanya, walaupun bangunan rumah penduduk tidak ada kekhasan tersendiri, tetapi di seputar rumah ada aturan-aturan yang harus dipenuhi, di antaranya untuk letak rumah, letak pintu, letak tempat menyimpan beras atau goah, dan posisi kamar tidur. Hal itu terjadi karena sifat dari masyarakat Sunda itu sendiri. Hal tersebut diperjelas dalam Suhamiharja (1997, hlm. 166) bahwa masyarakat Sunda memiliki pengetahuan mengenai hal-hal yang menyangkut kehidupan mereka sendiri. Seperti pengetahuan mengenai ruang, waktu dan bilangan.

Tidak jauh dari rumah penduduk, banyak ditemukan saung lesung. Pada tahun 1965 masyarakat Banceuy masih 
menggunakan lesung untuk menumbuk padi. Tempat tersebut juga kerap dijadikan tempat pelaksanaan sejumlah upacara adat, tepatnya untuk acara tutunggulan. Selain itu, dalam melakukan upacara ruwatan bumi atau memperingati maulid Nabi Muhammad SAW dan upacara ritual lainnya, masyarakat Banceuy pergi ke situs makam Aki Leutik atau yang disebut sebagai Raden Ismail Shaleh dan Makam Eyang Ito yang dianggap masyarakat Banceuy adalah leluhur mereka yang mendirikan Kampung Banceuy, serta situs Mbah Natasingadiraksa (Suta, Wawancara tanggal 13 Februari 2016).

Sarana umum yang terdapat di dalam kehidupan masyarakat Banceuy, diantaranya adalah sarana pendidikan. Di sana hanya ada satu Sekolah Dasar. Kalaupun ingin melanjutkan ke jenjang yang lebih tinggi mereka bisa melanjutkan ke Tsanawiyah yang berada di Desa Sanca. Karena Tsanawiyah tersebut sudah didirikan pada tahun 1960 . Sedangkan jika ingin melanjutkan ke SMP Negeri atau SMA, mereka harus pergi ke Jalancagak dengan jarak 7-8 kilometer. Selain itu, masih di depan bangunan SD, hanya terpisah oleh jalan, terdapat Bale pertemuan (Bale musyawarah) yang berdiri sejak tahun
1965 yang dirintis oleh Wakil Asma atau dulu disebut sebagai bawahan lurah. Tempat tersebut digunakan untuk berbagai aktivitas yang bersifat komunal, seperti upacara, musyawarah, dan lainlain (Amar, wawancara tanggal 11 April 2016). Sarana peribadatan yang ada di Kampung Banceuy adalah 4 bangunan masjid. Pengelolaan sanitasi lingkungan tercermin pula dalam pola perkempungan Banceuy. Sampah rumah tangga biasanya dibakar atau dikubur dalam tanah. Pada tahun 1988 masyarakat Banceuy mendapatkan bantuan air bersih dari UNICEF. Namun, pada tahun 2003 MCK sudah tidak digunakan seperti pada tahun-tahun sebelumnya (Odang, wawancara tanggal 11 April 2016). Sarana prasana dan fasilitas yang ada di Kampung Adat Banceuy tidak dapat dipisahkan dengan latar belakang kehidupan masyarakat Banceuy itu sendiri. Masyarakat Banceuy memiliki sejarah yang panjang hingga dijadikan sebagai kampung adat oleh pemerintah.

Kampung Banceuy merupakan suatu kumpulan masyarakat yang memiliki ciri khas sebagai orang Sunda, karena bahasa yang digunakan secara turun temurun yaitu bahasa Sunda. Hal ini sejalan dengan Koentjaraningrat (1970, hlm. 300) yang mengatakan 
bahwa yang disebut dengan suku bangsa Sunda adalah orang-orang yang secara turun temurun menggunakan bahasa ibu bahasa Sunda. Namun, dalam kehidupan sehari-harinya masyarakat Kampung Banceuy tidak menggunakan bahasa Sunda yang terdapat dalam undak-unduk bahasa Sunda. Bahasa Sunda yang digunakan oleh mereka hanya terdiri atas bahasa "lemes" dan wanoh (kasar).

Nama Banceuy pada sebutan Kampung Banceuy, memang memiliki arti filosofis tersendiri. Kampung Banceuy dulunya bernama Kampung Negla. Kemudian secara berurutan datang 7 keluarga ke tempat tersebut. Mereka membangun rumah untuk menetap di sana. Ketujuh keluarga tersebut adalah keluarga Eyang Ito, $A k i$ Leutik dari Kampung Palasari, Aki Alman dari Kampung Cibeureum Subang, Aki Malim dari Limbangan Garut, Aki Ono dari Wanayasa Purwakarta, Aki Uti dari Kampung Palasari, dan Aki Arisam dari Kampung Citepus Palasari. Tidak berapa lama kemudian, tempat tinggal mereka tertimpa musibah angin puyuh. Rumah mereka hancur diterjang angin puyuh selama tiga hari, sehingga warga pindah ke Kampung sebelah yang pada selanjutnya dinamakan Kampung Banceuy. Setelah kejadian tersebut, muncul inisiatif masyarakat untuk bermusyawarah atau ngabanceuy menurut istilah mereka (Suta, wawancara tanggal 13 Februari 2016).

Tujuan mereka ngabanceuy adalah mencari cara untuk memberi kekuatan pada wilayah itu agar terhindar dari segala bencana. Untuk memutuskan hal itu, mereka mengundang seorang paranormal atau tukang ramal dari Desa Pasanggrahan yang bernama Uyut Artawijaya. Tukang ramal itu memberikan tiga petunjuk, yaitu:

1. Wilayah babakan Negla harus di pimpin oleh $A k i$ Ito dan keturunanya

2. Di wilayah itu harus dilaksanakan ruwatan bumi (ngaruwat bumi)

3. Nama kampung itu harus diganti

Dari adanya perjalanan panjang sejarah kehidupan masyarakat Banceuy dengan tradisi lisan yang selalu diwariskan kepada generasi penerusnya, seperti yang diungkapkan di atas mengenai peristiwa yang terjadi di masa lampau dalam kehidupan masyarakat Banceuy, terdapat perubahan-perubahan yang terjadi dalam kehidupan masyarakat Banceuy itu sendiri. Perubahanperubahan tersebut khususnya dalam aspek sosial maupun budaya. Nanang 
Martono (2012, hlm. 2) mengatakan bahwa studi perubahan sosial akan melibatkan dimensi ruang dan waktu. Dimensi ruang menunjukan pada wilayah terjadinya perubahan sosial serta kondisi yang melingkupinya. Dimensi waktu dalam studi perubahan meliputi konteks masa lalu (past), sekarang (present) dan masa depan (future). Perubahan yang terjadi dalam masyarakat Kampung Banceuy ini memiliki bentuk kausalitas (sebab-akibat) seperti yang diungkapkan oleh Pudjiwati Sajogyo (1985, hlm. 125) yang mengungkapkan bahwa manusia sebagai makhluk yang berakal berupaya mencari sebab-sebab dari setiap kejadian. Dengan mengetahui sebabnya berarti memahami akar dan sumber akibat atau kejadian begitupun dengan adanya fenomena perubahan sosial atau budaya.

Kampung Banceuy dalam rentang sebelum tahun 1965, memiliki sejarah yang sama dengan daerah lain ketika Indonesia waktu itu menjadi daerah jajahan Belanda dan Jepang. Jepang pada saat itu membuat camp untuk menyimpan persenjataan di Banceuy dan melakukan banyak kontak dengan masyarakat Banceuy. Begitupun dengan peristiwaperistiwa sejarah lainnya seperti peristiwa DI/TII pada tahun 1953 yang mengakibatkan pemukiman masyarakat
Kampung Banceuy ini terbakar dan mengakibatkan 2 orang korban jiwa dan 4 orang luka-luka. Adanya peristiwa tersebut memberikan pengaruh besar terhadap masyarakat Kampung Banceuy. Ketakutan dan ketegangan dihadapi oleh masyarakat Banceuy. Namun perkembangan selanjutnya Kampung Banceuy kembali aman (Suta, wawancara tanggal 13 Februari 2016).

Perkembangan masyarakat Kampung Adat Banceuyt tidak berhenti dalam kurun waktu yang diungkapkan di atas. Pada masa selanjutnya, masyarakat Banceuy memiliki banyak perubahanperubahan baik perubahan eksternal maupun internal. Faktor dari dalam diri masyarakat Banceuy atau dari luar merupakan hal yang paling penting dalam membahas perubahan-perubahan sosial dan budaya masyarakat Banceuy itu sendiri. Kehidupan masyarakat Banceuy dari masa ke masa memang memililiki banyak perubahan. Perubahan terjadi dimana-mana dan berjalan secara normal, karena itu masalah perubahan sosial lebih merupakan masalah tingkat perubahan ketimbang masalah ada atau tidaknya. Namun, yang perlu dibahas disini adalah mengapa masyarakat tertentu menunjukan perubahan yang luar biasa cepatnya atau luar biasa lembatnya, 
faktor apa yang mempengaruhinya dan bagaimana pengaruhnya (Lauer, 1993, hlm. 11).

Jika dilihat dari perkembangan masyarakat Banceuy dalam rentang tahun 1965-2008 banyak faktor eksternal yang mempengaruhi terjadinya perubahan sosial dan budaya dalam kehidupan masyarakat Banceuy. Faktor eskternal yang menyebabkan perubahanperubahan itu dimulai dari adanya pendirian suatu bangunan yang berfungsi dalam kehidupan masyarakat Banceuy, seperti yang terjadi rentang tahun 19652008 diantaranya didirikanya 1 Sekolah Dasar Negeri dan didirikan suatu Bale pertemuan pada tahun 1965 yang membuat mereka dapat berkumpul dengan para sesepuh adat dan masyarakat lainnya untuk bermusyawarah dan melakukan upacara-upacara adat, dan adanya saluran listrik di tahun 1995 yang mengubah kehidupan masyarakat Banceuy. Hal lain yang sangat menentukan perubahan yang sangat besar dalam kehidupan masyarakat Banceuy adalah dijadikanya Kampung Banceuy sebagai kampung adat pada tahun 1999.

Selain faktor-faktor eskternal di atas, terdapat pula faktor-faktor internal yang menyebabkan terjadinya perubahan sosial dan budaya dalam masyarakat
Banceuy. Hal tersebut seperti bertambah dan berkurangnya penduduk. Sejak rentang tahun 1965-2008 jumlah penduduk masyarakat Banceuy semakin bertambah. Hal tersebut diperlihatkan dengan masyarakat yang dari tahun ke tahun tumbuh menjadi masyarakat heterogen, tidak homogen seperti sebelum tahun 1995. Hal tersebut juga diperlihatkan dengan adanya penemuanpenemuan baru masyarakat Banceuy seperti dengan berkembangnya teknologi dan peralatan hidup. Seiring bertambahnya penduduk, masyarakat Banceuy dari masa ke masa menjadi masyarakat yang heterogen sehingga mengakibatkan adanya kontak dengan masyarakat di luar Banceuy. Kontak dengan masyarakat luar semakin deras terjadi apalagi ketika masyarakat Banceuy mendapatkan listik pada taun 1995, hal tersebut menyebabkan sekitar pada tahun 2002-2003an, keberadaan pohon aren (kawung) menarik minat para penyadap nira. Para penyadap nira itu diantaranya berasal dari Cianjur dan Ciamis. Komunitas Banceuy itu sendiri merasakan wilayah mereka dirajah oleh masyarakat luar (Amar, wawancara tanggal 11 April 2016).

Seiring dengan adanya faktor eksternal dan internal di atas, terdapat 
pula faktor pendorong dan penghambat terjadinya suatu perubahan dalam kehidupan masyarakat Banceuy. Faktor pendorong sangat menentukan terjadinya perubahan sosial budaya dalam kehidupan masyarakat Banceuy salah satunya adanya kontak dengan kelompok lain mengakibatkan berubahnya pola pikir dan kehidupan masyarakat Banceuy. Seperti hal nya perkembangan seni dan kebudayaan yang ada dalam masyarakat Kampung Banceuy. Salah satu kesenian yang berkembang dalam kehidupan masyarakat Banceuy adalah "celempungan". Kesenian tersebut memiliki perkembangan dari masa ke masa. Namun, setelah Kampung Banceuy dijadikan sebagai kampung adat, maka pada tahun 2006 salah satu tokoh seniman masyarakat Banceuy memiliki pemikiran untuk mengembangkan kesenian celempungan. Hal ini ditunjukkan ketika seniman tersebut berkunjung ke beberapa komunitas lain di luar Kampung Banceuy bahkan ke beberapa kota.

Selain itu Keberagaman pekerjaan pada masyarakat memperlihatkan bahwa pendidikan masyarakat Banceuy mulai berkembang pesat. Pada rentang waktu 43 tahun ini, perkembangan tingkat pendidikan masyarakat Banceuy dapat terlihat dari masa ke masa. Tingkat pendidikan masyarakat meningkat dari tahun ke tahun seiring berjalanya waktu dan adanya pembangunan pendidikan formal maupun informal. Endang Supriatna dkk dalam (2010, hlm. 17) mengatakan bahwa pada masa-masa sebelumnya, kendala dalam tingkat pendidikan masyarakat Banceuy adalah mereka melihat contoh tetangga yang berpendidikan tinggi, tetap kembali menjadi petani. Dalam padangan mereka untuk menjadi petani tidak perlu sekolah tinggi, yang membutuhkan biaya cukup besar bagi mereka. Oleh karena itu, mereka cenderung memilih belajar membantu orangtua di sawah, beternak, atau menjual hasil bumi. Namun, pada masa selanjutnya pendidikan formal menjadi kebutuhan bagi masyarakat. Hal tersebut ditambah dengan adanya kebijakan pemerintah menetapkan kampung adat banceuy sebagai wisata alternatif tahun 1999-2000.

Namun, dengan adanya faktor pendorong di atas, terdapat pula faktorfaktor penghambat terjadinya perubahan sosial budaya dalam kehidupan masyarakat Banceuy. Sebelum tahun 1995 tidak banyak masyarakat Kampung Banceuy melakukan kontak dengan masyarakat lain. Keadaan masyarakat Banceuy sangat sepi berbeda dengan 
ketika adanya listrik pada tahun 1995 dan ketika dijadikannya Kampung Banceuy sebagai kampung adat atau kampung budaya pada tahun 1999 (Lilis, wawancara tanggal 13 Februari 2016). Selain faktor tersebut, faktor lain yang menghambat timbulnya perubahan sosial budaya masyarakat Kampung Banceuy adalah keyakinan mereka yang percaya bahwa masyarakat Kampung Banceuy harus melestarikan apapun yang dilakukan oleh para leluhur mereka. Hal tersebut memperlihatkan bahwa sikap masyarakat masih tradisionalistis. Hal lain yang dapat menghambat perubahan sosial dan budaya yang terjadi dalam kehidupan masyarakat Banceuy adalah adanya peranan kepala adat. Jika dilihat dari dinamika kehidupan masayarakat Kampung Banceuy, peranan kepala adat dari waktu ke waktu semakin berkurang. Namun, peranan kepala adat ini mempengaruhi perubahan sosial dan budaya yang terjadi dalam kehidupan masyarakat Banceuy. Hal tersebut memperlihatkan bahwa adanya kepentingan-kepentingan yang telah tertanam dengan kuat atau vested interest.

Dari adanya faktor eksternal dan internal ataupun faktor pendorong dan penghambat yang diungkapkan pada pembahasan sebelumnya, perubahan- perubahan tersebut akan berpengaruh terhadap nilai-nilai yang tidak mengikat salah satunya fenomena perubahan yang terjadi seperti stratifikasi sosial, gotong royong, dan gaya hidup masyarakat Kampung Adat Banceuy. Namun, dengan adanya perubahan yang terjadi pada nilainilai yang tidak mengikat, perubahanperubahan sosial dan budaya tersebut tidak terjadi pada nilai-nilai yang tidak mengikat seperti adat istiadat yang diungkapkan dalam upacara-upacara adat dalam kehidupan masyarakat Banceuy.

Kehidupan masyarakat Banceuy tidak akan terlepas dari apapun yang dilakukan oleh para leluhurnya. Mereka masih menganggap bahwa mereka merupakan bagian dari alam. Dengan adanya hal tersebut, maka apapun yang dilakukan dalam kehidupanya, selalu dilakukan berbagai macam ritual atau disebut sebagai upacara adat. Upacara adat atau yang disebut sebagai adat istiadat merupakan bagian dari sebuah kebudayaan yang ada dalam kehidupan masyarakat Banceuy. Adapun E.B Taylor dalam Soekanto (1995) pernah mencoba memberikan definisi mengenai kebudayaan sebagai berikut:

Kebudayaan adalah kompleks yang mencangkup pengetahuan, kepercayaan, kesenian, moral, hukum, adat istiadat dan lain kemampuan-kemampuan serta 
kebiasaan-kebiasaan yang didapatkan oleh manusia sebagai anggota masyarakat (hlm. 188).

Jika melihat pernyataan di atas jelas bahwa adat istiadat merupakan bagian dari kebudayaan atau kebiasaan yang dilakukan oleh masyarakat. Adat istiadat atau upacara-upacara adat yang ada di Kampung Adat Banceuy adalah adanya upacara diseputar aktivitas pertanian seperti upacara Mapag Cai, upacara hajat solokan, upacara ngaruwat bumi, upacara netepkeun dan nganyaran. Sedangkan upacara yang berkaitan dengan peristiwa alam atau epidemi adalah upacara hajat lingkungan atau hajat wawar.

Adanya nilai-nilai tradisi yang masih dipegang teguh oleh masyarakat Kampung Banceuy di atas, mengakibatkan nilai-nilai tersebut sangat mengikat bagi masyarakat Kampung Banceuy. Karena adanya hal-hal yang harus dilakukan dan tidak boleh ditinggalkan. Upacara-upacara adat yang telah dijelaskan pada pembahasan sebelumnya merupakan nilai-nilai yang mengikat bagi masyarakat Banceuy. Sehingga jika tidak dilakukan atau adanya pelanggaran akan mengakibatkan sesuatu yang buruk bagi kehidupan mereka. Hal tersebut disebutkan dalam J. Dwi Narwoko dan Bagong S. (2013, hlm.
55) dikarenakan adat istiadat (custom) merupakan bagian dari kontrol sosial, anggota masyarakat yang melanggar adat-istiadat, akan menderita sanksi yang keras dan kadang-kadang secara tidak langsung diperlakukan. Hal tersebut tercermin ketika diadakan upacara "ngaruwat bumi" yang selalu dilakukan setiap tahun dan tidak pernah ditinggalkan oleh masyarakat Kampung Banceuy. Cara-cara kehidupan lain seperti dilarang menumbuk padi pada setiap Senin, Selasa, Jumat dan tanggal 14 pada setiap bulan kalender Hijriah, ini disebut larangan Nyi Pohaci. Arah menghadap pintu tidak boleh sembarangan, melainkan harus menghadap Selatan atau Utara dan caracara kehidupan lainnya.

Sebenarnya dalam kehidupan masyarakat Kampung Banceuy tidak terlalu terlihat adanya sanksi bagi masyarakatnya yang melanggar nilainilai kehidupan masyarakat Kampung Banceuy. Namun, mereka tidak takut terhadap sanksi yang diberikan oleh manusia atau sesama masyarakat Kampung Banceuy sendiri. Tetapi takut akan sanksi yang diberikan oleh para leluhur mereka dengan bentuk bencana (Suta, wawancara tanggal 13 Februari 2016). 
Nilai tradisi yang pernah dilanggar oleh masyarakat Kampung Banceuy yaitu, mengenai acara-acara yang dilakukan dalam melaksanakan ngaruat bumi dengan tidak melakukan acara numbal kerbau yang mengakibatkan ternak sapi masyarakat Kampung Banceuy semuanya mati secara tiba-tiba. Hal ini dianggap oleh masyarakat Banceuy bahwa para leluhur marah kepada mereka dikarenakan tidak memberikan tumbal kerbau. Selain itu juga, dalam acara helaran pernah terjadi tidak memakai kuda kosong yang mengakibatkan terjadinya hujan angin yang sangat besar di Kampung Banceuy (Miska, wawancara tanggal 11 April 2016). Kehidupan masyarakat Kampung Banceuy dalam melaksanakan nilai-nilai tradisi memang tidak ada ketentuan hukum yang jelas serta tidak adanya sanksi. Namun, dalam diri masyarakat sendiri sudah tertanam bahwa sanksi tersebut akan berupa sebuah bencana bagi masyarakat Kampung Banceuy bukan hanya pada satu individu sajah tetapi seluruh masyarakat Kampung Banceuy.

Adanya kepercayaan yang tertanam dalam kehidupan masyarakat Banceuy merupakan salah satu usaha yang dilakukan masyarakat Banceuy untuk mempertahankan adat istiadat Kampung
Banceuy itu sendiri. Menurut masyarakat Banceuy, upacara-upacara adat ini selalu dilakukan karena mereka sudah terbiasa dalam melakukanya. Hal itu terjadi karena menurut mereka walaupun sejarah Kampung Banceuy dari para leluhurnya sangat baik, tetapi kalau generasinya tidak mengelolanya dengan baik mungkin Kampung Banceuy ini tidak akan baik dan mungkin saja nilai dan tradisinya akan menghilang (Amar, Wawancara tanggal 11 April 2016). Jika melihat pada jaman memang sangatlah berbeda, namun masyarakat Kampung Banceuy selalu menerapkan suatu pedoman hidup yang tercermin dalam sebuah slogan Kampung Banceuy sendiri yaitu "Ngindung ka Waktu Ngula ka Jaman". Kehidupan masyarakat Kampung Banceuy memang memiliki perubahan khususnya dalam bidang sosial dan budaya. Namun, satu hal yang mereka tetap pertahankan adalah tradisi nilai para leluhur mereka.

Secara lahiriah tetap saja jika upacara-upacara itu tidak dilaksanakan selalu ada yang menanyakan kapan akan dilaksanakan upacara yang seharusnya rutin dilaksanakan. Hal tersebut bisa dilakukan dengan melakukan upacara wawar yang merupakan upacara buruan dimana setiap individu mengingatkan 
individu lainnya untuk melaksanakan upacara adat yang akan dilakukan. Selain itu, hal-hal lain yang mengingatkan masyarakat Kampung Banceuy untuk melaksanakan upacara adat biasanya selalu ada saja yang mengingatkan seperti hal nya para leluhur yang datang dalam mimpi atau juga datang kepada masyarakat Kampung Banceuy yang mudah dimasuki hal-hal gaib atau orang Sunda menyebutnya "Leumpeuhyuni". Sehingga tradisi atau upacara selalu dilaksanakan dan tidak pernah dilanggar (Miska, wawancara tanggal 11 April 2016).

Usaha lain yang dilakukan untuk mempertahankan adat istiadat adalah adanya peran sesepuh adat yang memberikan petuah dan menjelaskan tentang riwayat berdirinya Kampung Banceuy. Pemberian petuah paling sering dilakukan pada saat:

1. Pengajian oleh warga Banceuy yang diselenggarakan setiap malam Jum'at. Pada saat itu petuah atau nasehat sesepuh harus dilakukan oleh masyarakat Banceuy khususnya para generasi muda kampung adat Banceuy yang belum mengerti akan adat istiadat yang berlaku dalam kehidupan masyarakat Banceuy.

2. Musyawarah atau adanya pertemuan saat pelaksanaan upacara adat, sesepuh selalu memberikan nasihat dan mengingatkan warga masyarakat Banceuy akan adat istiadat yang harus tetap dilaksanakan dan dilestarikan (Miska, wawancara tanggal 11 April 2016).

Selain usaha yang dilakukan dalam diri masyarakat Banceuy itu sendiri, usaha-usaha lain juga dilakukan oleh masyarakat Banceuy dengan cara meningkatkan peran serta generasi muda hingga memasukan nilai-nilai kehidupan masyarakat Banceuy yang sangat diperlukan ke dalam dunia pendidikan. Hal tersebut dijalankan oleh masyarakat Banceuy dalam pembelajaran seni dan budaya di PAUD yang mulai didirikan pada tahun 2008. Hal ini dipercaya oleh masyarakat Banceuy bahwasanya nilainilai yang ada dalam masyarakat Banceuy dapat terus tertanam sejak masih kanak-kanak. Karena anak-anak itu akan melakukanya jika mereka sudah terbiasa sejak kecil di didik tentang nilai-nilai kehidupan masyarakat Banceuy. Selain menerapkan nilai-nilai masyarakat 
Banceuy pada tingkat kanak-kanak (PAUD), dalam pembelajaran di sekolah dasar yang ada di Kampung Banceuy pun selalu diberikan pengetahuan mengenai nilai-nilai kehidupan masyarakat Banceuy seperti hal nya ketika adanya kegiatan kenaikan kelas yang diajarkan dan diperlihatkan adalah seni tradisi khas masyarakat Banceuy tidak menggunakan seni modern. Selain itu dalam pembelajaran juga ada guru misalnya dalam pembelajaran Pendidikan Kewarganegaraan memasukan kehidupan nyata dengan pembelajaran kontekstual yang dilakukan masyarakat Banceuy seperti rasa simpati dan empati yang tertanam dalam sistem gotong royong masyarakat Banceuy seperti ngahiras dan arisan, serta bagaimana cara menghormati yang lebih tua tertanam dalam menghormati para sesepuh dan leluhur Kampung Banceuy yang tertuang dalam upcara-upacara adat yang ada dalam masyarakat Banceuy (Odang, wawancara tanggal 30 Juni 2016).

Selain dalam pendidikan formal, pendidikan mengenai seni dan budaya dalam kehidupan masyarakat Banceuy pun dilakukan di luar sekolah seperti hal nya ketika akan diadakan acara 17 Agustusan, seniman-seniman masyarakat Banceuy selalu memberikan pelatihan mengenai seni-seni tradisional yang ada dalam masyarakat Banceuy seperti dalam memainkan celempungan ada seorang guru yang membawa alat kesenian seperti celempungan ke dalam lingkungan sekolah, ikut serta dalam upacara-upacara adat agar generasi muda Banceuy mengetahui dan rasa memilikinya tertanam sejak dini (Odang, wawancara tanggal 30 Juni 2016). Jelas rasanya jika dari masa ke masa masyarakat Banceuy masih mempertahankan adat istiadat yang ada sejak dulu para leluhurnya mendirikan kampung tersebut.

\section{SIMPULAN}

Masyarakat tradisional Kampung Banceuy terletak di Desa Sanca, Kecamatan Ciater, Kabupaten Subang. Masyarakat tradisional Kampung Banceuy merupakan kesatuan hidup manusia yang berinteraksi menurut suatu sistem adat istiadat tertentu yang bersifat kontinu, dan yang terikat oleh suatu rasa identitas bersama. Adat istiadat yang selalu dipegang teguh oleh masyarakat Banceuy, tentunya memiliki arti filosofis tersendiri. Dalam sejarahnya, Kampung Banceuy dulunya bernama Kampung Negla. Kemudian secara berurutan datang 7 keluarga ketempat tersebut. Mereka membangun rumah untuk 
menetap disana. Tidak berapa lama kemudian, tempat tinggal mereka tertimpa musibah angin topan. Rumah mereka hancur diterjang badai topan. Setelah kejadian tersebut, muncul inisiatif warga masyarakat untuk bermusyawarah atau ngabanceuy.

Perubahan-perubahan yang terjadi dalam kehidupan masyarakat Banceuy tentunya tidak berjalan begitu saja tanpa sebab. Terdapat berbagai faktor yang mempengaruhi terjadinya perubahanperubahan tersebut. Faktor yang menyebabkan perubahan-perubahan yang ada dalam masyarakat Banceuy ada yang merupakan faktor eksternal seperti adanya perubahan fisik yang terjadi dalam kehidupan masyarakat Banceuy dan faktor internal yang terjadi dalam diri masyarakat Banceuy itu sendiri. Namun, dari adanya hal tersebut terjadi faktor yang mendorong serta menghambat terjadinya suatu perubahan dalam kehidupan masyarakat Banceuy. Salah satunya adalah adanya kontak dengan kebudayaan lain yang datang bersamaan dengan dijadikannya Kampung Banceuy sebagai Kampung Adat. Sedangkan faktor penghambat adalah sifat tardsionalistis atau kepercayaan yang selalu dipegang teguh oleh masyarakat dan peranan kepala adat yang sangat kuat.
Dalam perkembangan masyarakat Banceuy ada nilai-nilai yang tidak mengikat dan ada nilai-nilai yang mengikat. Perubahan-perubahan baik sosial ataupun budaya akan mempengaruhi kedua nilai-nilai tersebut. Fenomena-fenomena perubahan itu terjadi kepada nilai-nilai yang tidak mengikat seperti pada sistem gotong royong, stratifikasi sosial, serta gaya hidup masyarakat Banceuy. Sedangkan perubahan-perubahan tersebut tidak berpengaruh kepada nilai-nilai yang mengikat seperti adat istiadat. Hal tersebut dikarenakan adanya sanksi yang diberikan dan usaha mempertahankan qdat istadat.

\section{DAFTAR PUSTAKA}

Asshiddiqie, J. (2010). Konstitusi masyarakat desa (piagam tanggungjawab dan hak asasi warga desa) (online). Tersedia: (http://jimly.com/makalah/namafil e/176/KONSTITUSI_MASYARA KAT DESA.pdf)

E. Supriatna dkk. (2010). Kajian nilai budaya tentang mitos dan pelestarian lingkungan pada masyarakat Banceuy Kabupaten Subang. Subang: Departemen Kebudayaan dan Pariwisata Balai Kajian Sejarah dan Nilai Tradisional Bandung.

Firth, R dkk. (Tanpa Tahun). Tjiri-tjiri dan alam hidup manusia suatu pengantar antropologi budaya. Bandung: Vorkink-Van Hoeve 
Gottschalk, L. (1986). Mengerti sejarah (terjemahan

Nugroho

Notosusanto). Jakarta: UI Press

Ismaun. (2005). Pengantar sejarah sebagai ilmu dan wahana pendidikan. Bandung: Historia Utama Press

Koentjaraningrat. (1970). Manusia dan kebudayaan di Indonesia. Jakarta: Penerbit Djambatan.

Koentjaraningrat. (2009). Pengantar ilmu antropologi. Jakarta: PT. Rineka Cipta

Lauer, R.H. (1993). Perpektif tentang perubahan sosial. Jakarta: Rineka Cipta.

Martono, N. (2012). Sosiologi perubahan sosial (perspektif klasik, modern, posmodern, dan poskolonial). Jakarta: Rajawali Pers

Narwoko J. Dwi dan Bagong S. (2013). Sosiologi teks pengantar dan terapan. Jakarta: Kencana

Sajogyo, P. (1985). Sosiologi pembangunan. Jakarta: Fakultas Pasca Sarjana IKIP Jakarta

Suhamiharja, A. S . (1997). Wujud arti dan fungsi puncak-puncak kebudayaan lama dan asli bagi masyarakat pendukungnya di jawa barat. Bandung: Departemen Pendidikan dan Kebudayaan Direktorat Jenderal Kebudayaan Direktorat Sejarah dan Nilai Tradisional Bagian Proyek Pengkajian dan Pembinaan NilaiNilai Budaya Jawa Barat 1995/1996

Supriatna, N. (2013). Green history: belajar dari pengalaman historis hubungan manusia dengan alam. Jakarta: Kongres APPS.

\section{Wawancara}

Wawancara dengan Rohana Odang, seorang seniman yang mengembangkan kesenian buhun di Kampung Banceuy (42 Tahun), tanggal 16 Desember 2015 di Kampung Banceuy Desa Sanca Kecamatan Ciater Kabupaten Subang, Jawa Barat

Wawancara dengan Lilis Khodijah yang merupakan istri dari orang yang berpengaruh dalam menjadikan Kampung Banceuy sebagai kampung adat (47 Tahun), tanggal 13 Februari 2016 di Kampung Banceuy Desa Sanca Kecamatan Ciater Kabupaten Subang, Jawa Barat

Wawancara dengan Abah Suta yang merupakan sesepuh Kampung Adat Banceuy (76 Tahun), tanggal 13 Februari 2016 di Kampung Banceuy Desa Sanca Kecamatan Ciater Kabupaten Subang, Jawa Barat

Wawancara dengan Aki Miska yang merupakan sesepuh Kampung Adat Banceuy (81 Tahun), tanggal 11 April 2016 di Kampung Banceuy Desa Sanca Kecamatan Ciater Kabupaten Subang, Jawa Barat

Wawancara dengan Amar yang merupakan seniman yang mengembangkan kesenian celempungan di Kampung Banceuy (56 Tahun), tanggal 11 April 2016 di Kampung Banceuy Desa Sanca Kecamatan Ciater Kabupaten Subang, Jawa Barat 